Article

\title{
Scoring Model of the Financial Health of the Electrical Engineering Industry's Non-Financial Corporations
}

\author{
Sylvia Jenčová ${ }^{1, *}$, Róbert Štefko $^{2}$ and Petra Vašaničová ${ }^{3}$ \\ 1 Department of Finance, Faculty of Management, University of Prešov, 08001 Prešov, Slovakia \\ 2 Department of Marketing and International Trade, Faculty of Management, University of Prešov, \\ 08001 Prešov, Slovakia; robert.stefko@unipo.sk \\ 3 Department of Mathematical Methods and Managerial Informatics, Faculty of Management, \\ University of Prešov, 08001 Prešov, Slovakia; petra.vasanicova@unipo.sk \\ * Correspondence: sylvia.jencova@unipo.sk; Tel.: +421-917-637-341
}

Received: 15 June 2020; Accepted: 21 August 2020; Published: 24 August 2020

\begin{abstract}
The aim of this paper is to estimate the probability of bankruptcy of the companies from the Slovak electrical engineering industry based on data obtained from financial statements. Parameters of the predictive model were estimated using binary logistic regression. This model is able to predict the probability of a company's bankruptcy based on values of significant explanatory variables (accounts payable turnover ratio (APTR), return on sales (ROS), quick ratio (QR), financial leverage (FL), net working capital/assets (NWC/A)). The model is constructed using the financial data of a large sample of electrical engineering companies from 2017. Resulting estimated odds ratios show that, in the electrical engineering industry, ROS, QR, and NWC/A significantly reduce the likelihood of bankruptcy. In other words, if these financial indicators increase, the probability of bankruptcy decreases. Our results are also applicable to other industries connected with industrial production, especially the mechanical engineering industry.
\end{abstract}

Keywords: scoring model; financial health; electrical engineering industry; Slovakia; logistic regression

\section{Introduction}

The electrical engineering industry is linked with new initiatives and developments in order to meet the increased energy demands around the world. It is; therefore, essential that companies operating in this industry are financially sound. The electrical engineering industry is one of the dominant sectors of the Slovak industry. The development of the electrical engineering industry depends primarily on the automotive industry, where Slovakia is a world leader in motor vehicle production per capita. In 2016, 1.04 mill motor vehicles were made in Slovakia, in 2019, it was 1.1 mill. A share of industry in Slovak GDP is $23.9 \%$, of which industrial production is $18.9 \%$ [1]. The electrical engineering industry has a long tradition in Slovakia and is one of the main pillars of this country's industry. Through its synergistic effect, it increases the quality of production of other industries. Slovak electrical engineering industry produces products of high and medium-demanding technology and with high added value, while localization quotient is higher than 1 . According to the sales in 2017, manufacture of electrical equipment ranked first, and manufacture of computer, electronic and optical products ranked seventh among all industries in Slovakia.

The origin of the electrical engineering industry dates back to the nineteenth century. Mládek [2] studies the qualitative and quantitative aspects of the electrical engineering industry and highlights the production of washing machines, televisions, and television sets. The industry supplied motors, wires, and equipment for the production, transmission, and use of electrical energy. At the beginning of the 
economic transformation in the nineties, this industry was marked as a sector without perspective. During privatization, holders of investment coupons were not advised to invest their assets in this industry. A positive turnaround has been taking place since 1995, after the entry of foreign capital. Siemens, which is now a key company, started at this time, but other foreign investors have entered and are entering the market. Siemens mainly produced alternators, dynamos, switchboards, and later also pumps, transformers, elevators, and cranes. In addition, the company supplied equipment for the municipal power plant. Since 1996, almost the entire industry has been privatized. Since the mid-1990s, scientific and technological progress has led to a boom in this sector, in all economic and financial indicators. The inflow of foreign direct investment, which brings with it not only investment but also new technologies and know-how, determines this situation to the greatest extent, and; therefore, the Slovak electrical engineering industry is becoming competitive on domestic and especially on foreign markets. Dubcová, Midler [3], and Kulla [4] describe the time periods of the foreign capital inflow were directed to Slovakia. In the 1990s of the twentieth century, it was investments related to the automotive industry (electric cables, lighting devices); at the beginning of the twenty-first century, the investments connected with the consumer electronics sector. Foreign direct investment has mitigated the effects of the economic crisis. The development and position of the Slovak electrical engineering industry are analyzed in [4-10]. The genesis of this industry was studied also for the Federal Republic of Germany [11], Great Britain [12,13], and Austria [14]. At present, it is a constantly evolving sector in terms of competitiveness and a specific carrier of the latest results of science and technology. It has the potential for significant development in connection with the introduction of Industry 4.0 and Smart technologies. According to [15], there are a myriad of methods and approaches to assessing the creditworthiness of any firm, allowing one to predict possible bankruptcy. Financial institutions tend to keep their practices secret, defending this as their institutional know-how. However, financial indicators play an important role in all models. Sophisticated approaches require sophisticated statistical processes that work with historical time data and calculate the different probabilities of company default based on the values of certain financial indicators.

The Slovak electrical engineering industry operates not only thanks to large companies, but mainly due to the large number of small and medium-sized enterprises with a long tradition. Therefore, the aim of this paper is to estimate the probability of bankruptcy of the companies from Slovak electrical engineering industry. So far, a number of models have been developed to predict a company's bankruptcy. However, each model is designed for different conditions, business environments, industries, and countries. Universal models are often not suitable because they cannot be repeated due to the limited number of available financial indicators. At present, we are not aware of the existence of the model that predicts the bankruptcy of companies operating in the Slovak electrical engineering industry. In this article, we fill this gap by providing statistically a significant logit model composed of financial indicators available from each standard financial statement.

\section{Literature Review}

The issue of financial health has been the subject of many studies since the early 19th century. Different approaches and methods have been used to assess the financial health of businesses. Tamari [16], the Balance Analysis System by Doucha [17], and the Kralicek Quick Test, all lead to the development of the scoring method. The purpose of these creditworthy models is to determine the creditworthiness of a business, in an effort to determine whether the business is financially sound or has financial difficulties.

Mathematical and statistical methods used are based on one-dimensional discriminant analysis. Fitzpatrick [18] compared the development of indicators in solvent and insolvent businesses, and was the first who use these indicators with regards to corporate bankruptcy. He found that the indicators most important in predicting the financial situation of a company are the ratios Equity/Liabilities and EAT/Equity. According to [19], the ratio of Working Capital/Assets is the best indicator. In the following years, Mervin [20], Chudson [21], Walter [22], and Jackendoff [23] performed additional 
studies. In his proposal for future studies, Beaver [24] outlined the possibility that the use of multiple indicators may have higher predictive power than the use of just one indicator, thus starting a new era in the development of predictive bankruptcy models [25].

\subsection{New Era in Forecasting Financial Developments in Enterprises}

\subsubsection{Multiple Discriminant Analysis}

New era in forecasting financial developments in enterprises is dated since 1968. Altman [26-28] based his studies on multiple discriminant analysis (MDA). The first and the most widely used model based on this method was five-factor model for manufacturing enterprises [26] that achieved a $95 \%$ accuracy a year ahead, $72 \%$ accuracy two years ahead, and $48 \%$ accuracy ahead of three years. The underlying information source from which the Altman model is based is empirical data from 33 random enterprises taken over the previous five years before their bankruptcy, and similar data for 33 prosperous businesses over the same time period. A sample of bankrupted businesses consisted of those who filed a bankruptcy petition from 1946 to 1965. Altman examined 22 potentially useful benchmarking ratios, which he split into five core categories: liquidity, profitability, indebtedness, solvency, and activity. Subsequently, using the discriminant analysis, he determined the weight of the individual ratios. The dividing value was set to $Z=2.675$, with enterprises with a $Z$-score lower than the dividing line threatening bankruptcy. In 1983, Altman revised its model because its original model could only be applied to companies traded on capital markets. The multiple discriminant analysis was used also in [29-41], and others.

In the Czech Republic, there is a popular but rarely used model developed by Czech authors named as IN95, IN99, IN01, and IN05. The index was created and tested on data from predominantly medium and large industrial enterprises, so the results of the model will have the best reporting ability for such businesses. If the test results in an IN $<0.9$, then the company is heading for bankruptcy [42]. For UK firms, a model created by Taffler [33,34] is used to make these determinations. Marais [38] developed model for UK manufacturing and distribution companies, Sinkey [31] designed model exclusively for banks. For Germany, Switzerland and Austria, Beerman [32] created a discriminant index function so called creditworthiness index. Virag, Nyitrai [43] introduced prediction model for the conditions of Hungary. Based on multiple discriminant analysis, similar work was done for Slovakia by [44-54]. Study of Delina, Packova [25] focuses on validation of selected bankruptcy models based on the data mining approach. The results show that models for foreign countries are not suitable for the conditions of the Slovak economy.

Most studies have shown that the underlying assumptions of MDA (specifically, the independent variables included in the model, from a statistical point of view, correspond to the normal probability distribution; variance-covariance matrix groups, the dependency matrix is random among groups of declining or prosperous enterprises) are violated. Due to these problems, new methods have been developed over time involving logit analysis or neural networks.

\subsubsection{Logit Analysis and Neural Networks}

The author of the logit bankruptcy models is Ohlson [55], who created his model based on a sample of 105 bankrupt and 2058 prosperous corporations traded on the US stock exchange for at least three years. Used data from 1970-1976 was collected from the Compustat database. The analysis was based on nine indicators, but the choice of these indicators was not theoretically substantiated. Ohlson logit model identified bankruptcy with $96 \%$ accuracy one and two years ahead. Zavgren [56] created a seven-factor logit model for manufacturing companies that achieved a $69 \%$ accuracy of predicting bankruptcy for one to five years into the future. Jabeur [57] developed a model for French companies on a sample of 400 prosperous and 400 non-prosperous companies, while he included 33 financial ratios in the model. Alaminos et al. [58] presented a methodological framework of logistic regression to compile predictive models of bankruptcy in Asia, Europe, and America, as well as other global models 
for the whole world. The goal was to create a global model with a high probability of bankruptcy in any region of the world. Wang [59] created a logit model for Internet companies only. For the construction industry, Marcinkevičius, Kanapickiené [60] applied such a model for Lithuania, and Slavíček, Kuběnka [61] for the Czech Republic using a sample of 1292 companies, while a probability of bankruptcy was $94 \%$. Return of assets, inventory turnover, current ratio, and overall indebtedness are financial indicators influencing bankruptcy. Jakubík, Teplý [62] developed a model that covered all financial areas and used factors such as financial leverage, interest coverage, gross profit margin, return on equity, inventory turnover, and cash ratio. Gurný, Gurný [63] generated a model for financial corporations, in which the main factors were logarithm of total assets, return on average equity, and problem loans on gross loans. The scoring model for Czech companies of Valecký, Slivková [64] has the accuracy of bankruptcy prediction equal to $79.34 \%$. For the purposes of the empirical model, they use the financial statements of 400 companies. Their results show that ROA, ROS, cash ratio, quick ratio, and added value to sales ratio have a positive impact on bankruptcy, in other words, with their increasing value, the probability of bankruptcy decreases. On the other hand, overall indebtedness has a negative impact. It follows that the model represents the area of profitability, indebtedness, but also liquidity. For Slovakia, the main prediction models were developed by [65-69]. Using the sample of 500 prosperous and 500 non-prosperous companies, Kovacová, Klieštik [68] designed a scoring model for Slovak companies, while the probability of bankruptcy is $86.7 \%$. In their model, eight variables influence bankruptcy, specifically net return on total income, current ratio, net working capital ratio, retained earnings to total assets ratio, total debt to total assets ratio, current debt to total assets ratio, equity to assets ratio, and current assets to total incomes ratio. Harumová, Janisová [69] developed scoring model for small and medium enterprises based on data on enterprises from Prešov Region and Kosice Region of the Slovak Republic. They assumed that the scoring function would be useful in the companies' evaluation and would find application in intercompany comparisons. They confirm this hypothesis, while the scoring model with a probability of $88 \%$ includes earnings before interest, taxes, depreciation and amortization (EBITDA) to sales ratio, accounts payable turnover ratio, total assets turnover ratio, ROA, liabilities to cash flow ratio, and overall liquidity ratio.

Neural network models, due to their non-linear nonparametric properties, do not require the fulfilment of assumptions such as linearity, normality or independence of variables that are often violated in traditional statistical methods. The high predictive power of neural networks compared to conventional statistical methods was confirmed by [70]. Alaka et al. [71] provided a review of 49 important studies of bankruptcy prediction models from the period 2010-2015, which use multiple discriminant analysis, logistic regression, artificial neural networks, support vector machines, and others.

Unfortunately, all the presented studies cannot be applied or generalized to the conditions of Slovak electrical engineering companies, as they were created in different countries, adapted to different economic conditions and political decisions. Authors apply their models in financial or non-financial corporations in general. However, our model is the first developed and applicable model for non-financial corporations of the electrical engineering industry of the Slovak Republic, which is the most industrial state in the European Union. Therefore, we can formulate Hypothesis H1 as follows:

Hypothesis H1. Financial indicators (ratios) are sufficient to build a useful model for predicting probability of a company's bankruptcy.

The prediction model is a significant benefit for financial management, especially of medium and large corporations. To compare the determining factors and innovate the prediction model, data collection for the automotive, mechanical engineering, and metallurgical industries are currently underway at the academic level. At the same time, they performed the validation of the proposed model. 


\subsection{Financial Health of Non-Financial Corporations from the Electrical Engineering Industry}

A comprehensive view on the financial health of non-financial corporations from the Slovak electrical engineering industry is performed in $[10,11]$. According to their studies, looking at the financial health of enterprises from electrical engineering industry for the period from 2013 to 2017, using a multiple discriminant analysis and applying the Taffler's bankruptcy model, we can say that non-financial corporations in the electrical engineering industry were prosperous. The Taffler's model [72] actually analyzes the question of whether the company has a profile more similar to the group of companies in decline from which this model has been developed or falls into the profile of a group of thriving companies. Due to the retrospective and descriptive nature of the model, it is a suitable tool for analyzing the development of financial health of the company. According to the Springate bankruptcy model, $27.53 \%$ of companies can expect problems in the subsequent two years, specifically in 2018 and 2019. According to the Aspekt Global Rating calculating for the period 2012-2016, the rating AAA (the optimal business entity) dominated and was reached by $26.27 \%$ of enterprises; on the other hand, 8.02\% were on the brink of bankruptcy. In 2012, 39 companies, based on the interpretation of the results of this rating, acquired values below the threshold, whereas in 2016, it was 42 companies. The Aspekt Global Rating is an additive sum of seven ratios. According to this model, the number of entities on the brink of bankruptcy with significant risks and frequent crises increased.

\section{Materials and Methods}

\subsection{Research Sample}

The research sample consists of a set of 1000 largest non-financial corporations of the Slovak electrical engineering industry (file units) for the period 2017, whose ranking was obtained through the FinStat database according to the amount of generated revenues. The state indicators were obtained from the Financial Statements of the Slovak Republic. The companies showed similar results in terms of earnings before interest and taxes (EBIT) after three consecutive years. Out of 1000 businesses, 144 businesses reported zero revenue, 10 enterprises were in bankruptcy and did not publish financial statements, and; therefore, were not included in the analysis. A total of 856 enterprises entered the analysis, of which 6 enterprises were excluded, as there was a problem with missing values in several indicators. Concerning the subject of business activity, the industrial structure is changing. Therefore, it is necessary to monitor NACE (numbers used for all industries and service activities in the European Union) in the financial statements of each fiscal year. In 2017, 1521 Slovak companies belonged to the NACE Division 27-Manufacture of electrical equipment, and 953 companies were from NACE Division 26-Manufacture of computer, electronic and optical products.

The model and its predictive ability will be directly proportional to the quality of the data that is compiled. Most models use information from the annual financial statements taken from the Register of Financial Statements of the Slovak Republic. In the company's financial statements, the entire production process of the company-its conditions, its progress and its results—is very compressed. The reason for using financial indicators is that they are clear objective values and that they are based on publicly available information. In prediction of bankruptcy on the basis of ratios, some authors $[73,74]$ implicitly assume that annual financial statements provide a true and fair view of the company's financial position. However, it is obvious that many annual financial statements are unreliable, and they are not correct or true. It is generally known that bankrupt firms hire, when they are close to bankruptcy, adjusting their earnings in an effort to give a more positive picture of their financial situation. On the other hand, failing companies are inflating their profits. Practice has shown that in light of actual bankruptcy, accountants will make a wide range of adjustments, which will ultimately decrease the financial performance of a company, and this produces inconsistencies with many of the financial indicators used in the bankruptcy models applied to that firm. Another set of problems arises from missing values (the problem can be mitigated by adding additional values or eliminating the 
business) and extreme values (the problem can be partially eliminated by removing extreme percentiles (e.g., 10th and 90th percentiles)). The data were processed using the SAS software provided by SAS Institute (Cary, SC, USA) and the open-source Gretl software.

\subsection{Logistic Regression}

Popular methods of business failure estimation are logit analysis [54] and probit analysis [75]. Models based on logit analysis assume a logarithmic probability distribution, and those based on probit analysis assume a cumulative probability distribution. Logistic regression models are a generalized version of the linear models that are used to predict a dependent variable. They are used to model the unilateral dependence between variables when the dependent variable is not continuous but is discrete (categorical). Independent variables can be continuous, discrete or categorical. Logistic regression does not require a normal distribution of input variables. This allows including indicators in the model, which in parametric discriminant analysis would not be possible to analyze. This method is used when data cannot be assumed to be normal, or constancy of variance. Before performing the analysis, it is not necessary to test the significance of each variable, as this selection is part of the logistic regression process. The logistic regression output can be interpreted directly as a probability of failure. An important advantage of the model is that the logit-score is between zero and one, which instantly indicates the probability of bankruptcy of the company. It is easy to interpret. Another advantage is that it can easily handle continuous and categorical variables. On the other hand, it requires assumptions about input data (e.g., multi-collinearity and outliers must not be present; therefore, it is necessary to monitor the accuracy of the assumptions when using this method). The main disadvantage of logit models lies in their extreme sensitivity to problem of multiple regressions, and it is; therefore, necessary to avoid the inclusion of highly dependent variables. Ratio indicators have the same reader or denominator, which can cause a serious problem regarding multiple dependences.

The conditional probability of occurrence of the desired event under the condition of the vector occurrence of the independent variables $x$ can be written as $p=P(Y=1 \mid X)$, where $Y$ is a binary variable that acquires two values (1-event (failure) occurred, 0 —event did not occurr); $X$ is a vector of explanatory variables; $p$ is probability of occurrence of the desired event, while the values are from the interval $(0,1)$. The probability ratio $p /(1-p)$ then expresses the chance of occurrence of the desired event (success) to the occurrence of the undesired event (failure). The relationship between the probability $p$ and the explanatory variable $X$ is non-linear and has the shape of a logistic curve. The logistic curve is an extended S-curve and takes values from the interval $(0,1)$. The S-curve (sigmoid) is approaching to 0 for $X$ close to minus infinity then begins to rise sharply. The functional probability values are close to 1 for the values of the explanatory variable $X$ close to infinity.

In order to use regression, the dependent variable is transformed into a continuous value by calculating the logarithm of the odds ratio (values from the interval $(-\infty ; \infty)$ ), while odds ratios and probabilities expressing the same information in a different form. Traditional equation of logistic regression model can be expressed by:

$$
\ln \left(\frac{p}{1-p}\right)=\ln \left[e^{\left(\beta_{0}+\beta_{1} x_{1}+\beta_{2} x_{2}+\ldots+\beta_{k} x_{k}\right)}\right]=\beta_{0}+\beta_{1} x_{1}+\beta_{2} x_{2}+\ldots+\beta_{k} x_{k} .
$$

By logit transformation (illustrated in Figure 1) we go from non-linear to linear dependence (i.e., the relation between the logarithm of the odds ratio) and the vector of the explanatory variables acquires a linear character and the equation of the logarithmic model has the form according to:

$$
\operatorname{logit}(p)=\ln \left(\frac{P(Y=1 \mid X)}{P(Y=0 \mid X)}\right)=\ln \left(\frac{p}{1-p}\right) .
$$




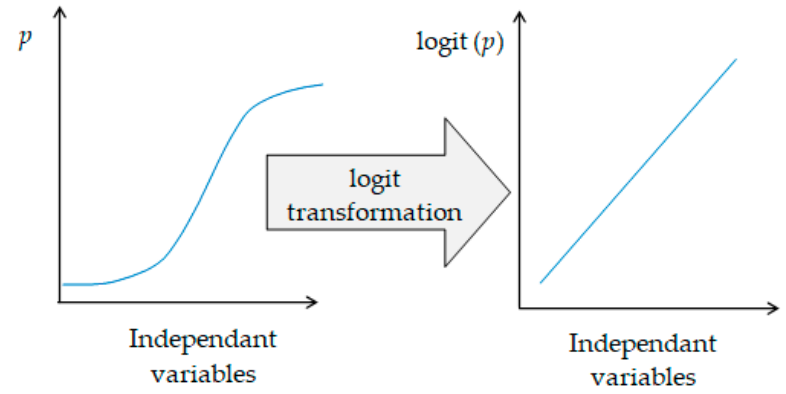

Figure 1. Logit transformation. Source: Own processing according to [76,77].

The logistic function expressing the relationship between the probability and the vector of the explanatory variables is nonlinear in character and thus takes the form of an exponential function and; therefore, the probabilities are transformed into logits. This transformation also guarantees that estimated probabilities are in the range 0 and 1 as expected from the probability definition. Probability calculation $p=P\left(Y=1 / X_{i}\right)$ results in

$$
p=\frac{e^{\beta_{0}+\beta_{1} X_{1}+\beta_{2} X_{2}+\ldots+\beta_{k} X_{k}}}{1+e^{\beta_{0}+\beta_{1} X_{1}+\beta_{2} X_{2}+\ldots+\beta_{k} X_{k}}}=\frac{1}{1+e^{-\left(\beta_{0}+\beta_{1} X_{1}+\beta_{2} X_{2}+\ldots+\beta_{k} X_{k}\right)}}=\frac{e^{z}}{1+e^{z}}=\frac{1}{1+e^{-z}},
$$

where $\beta$ is the vector of the estimated parameters indicating the weight (importance) of the individual input values $x_{i}$. The scalar product $x_{i}^{T} \beta$ is the score.

Logistic regression has no limitations on the distribution of explanatory variables, but they should not be highly intercorrelated.

Using nonlinear maximum likelihood estimation in logistic regression, estimates of logit model parameters were obtained. Principles of the maximum likelihood estimation (MML) are as follows:

- For any combination of possible values $\beta_{0}, \beta_{1}, \ldots, \beta_{n}$, the probability function tells us how likely we are to observe the data we observed if the model of the estimated parameter values were real parameters in the population.

- If we imagine a surface in which the range of possible values $\beta_{0}$ represents one axis and the range of $\beta$ is the second axis, the resulting probability function graph would look like a hill, where ML estimates would be the values of the parameters corresponding to the peak of that hill. The variance of possible estimates corresponds roughly to how quickly the slope changes, in a place near the top.

- $\quad$ MML is the common probability density of all observed responses $Y_{i j}$ as a function of model parameters $\beta_{0}, \beta, \sigma^{2}$.

- The principle is to find an estimate of the parameters $\beta_{0}, \beta, \sigma^{2}$, that maximize this probability function, leading to a solution that appears to be probable as much as possible (maximum likelihood).

- MLs have good properties: They are consistent (as the size of the sample increases, the estimates approximate to the actual value); they are efficient (they have the smallest possible variance in large selections); and asymptotic normal (approaching normal distribution).

Logit represents the slope of the regression parameter $\beta_{i}$, which is usually calculated by the Newton-Raphson method. Logistic regression allows one to verify the hypothesis that the regression coefficient in the logistic regression model differs from zero. Here it is zero if the probability ratio $\mathrm{L}_{(1)} / \mathrm{L}_{(0)}$ does not change and the probability is not affected. For large samples, Wald test criterion is used to quantify the statistical significance of the null hypothesis for individual estimates of regression coefficients. It has a chi-squared distribution with one degree of freedom. It represents the ratio of square of the regression coefficient estimation and its standard deviation. For data that produce large coefficient estimates, small insignificant Wald statistics may arise, which may lead to a misinterpretation 
of the explanatory variable as unimportant for the model. Mostly, logistic regression uses $\chi^{2}$ statistics to test whether or not the total set of independent variables is useful in classifying objects. A large value indicates that variables are useful. In the Hosmer-Lemeshow test $[78,79]$, the values of the explanatory variables are artificially distributed on the basis of estimated probabilities to approximately equally large groups, and the chi-square test is applied to them. Hosmer-Lemeshow statistics is counted as chi-square statistics from the table of actual and estimated probabilities of failure in each group. The $p$-value of this statistic confirms the validity of the null hypothesis that there are no major differences between expected and actual business failures.

\section{Results}

The scoring model of the financial performance of non-financial corporations and the probability of defaults was quantified according to the proposed model based on logistic regression. The aim of this model is to find a combination of indicators that together show the best predictive ability. For each type of information (quantitative, qualitative), a specific function can be developed. It requires knowing which indicators have good resolution and then compressing them into a synthetic discriminant variable. We determined the dependent (binary) variable on the basis of Act no. 513/1991 Coll. Commercial Code [80] as amended, which stated that a company will be considered to be in "crisis", if such company is bankrupt or endangered by bankruptcy. The bankruptcy of the company is defined in Act no. 7/2005 Coll. on Bankruptcy and Restructuring [81], while bankruptcy is expressed as the equity to liabilities ratio. Any electrical engineering company that has negative equity, or positive equity, but the ratio of its equity to liabilities is less than 6 to 100, is endangered by bankruptcy. In our analysis, a company in bankruptcy is denoted as 1 , otherwise 0 .

When looking for an optimal model based on enterprise data for 2017, we take into account the indicators of profitability $\left(x_{2}, x_{3}\right)$, activity $\left(x_{1}, x_{5}\right)$, indebtedness $\left(x_{6}, x_{7}\right)$, and liquidity $\left(x_{4}, x_{8}\right)$ (see Table 1). These indicators assess the ex-post financial situation of individual non-financial corporations. Liquidity indicators assess whether the company is able to pay short-term liabilities, whether it has enough capital to ensure the functioning of the company, and what is the capital structure of the company. Activity indicators show how long a company has tied up finances in inventories and whether the company is able to collect receivables on time. As the indebtedness increases, the return on equity increases, which is due to the growth of the tax shield, and at the same time as the indebtedness increases, the company's liquidity decreases. It is not possible to achieve high profitability and low liquidity in the company. If the company appears to be too liquid from the analyst's point of view, this view must be corrected by analyzing the turnover of groups of assets (inventories and receivables). The capital commitment in short-term assets does not bring the company any or only a small return. The company does not derive any income from holding a large number of current assets; there exists sunk capital and thus a decrease in profitability. Therefore, there is an indirect relationship between liquidity and profitability. As asset turnover grows, profitability grows. There are industries that achieve a high return on assets due to a high profit margin, or industries that achieve a high return on assets caused by a high assets turnover. The basic factors that affect profitability indicators include natural conditions, macroeconomic conditions, market conditions, production structure, procedures and technology used, degree of resources utilization used and use of work, quality of production, sales prices, cost, asset turnover, liquidity, business financing, and others. We did not include the return on equity ratio (ROE) in the ratios, as the negative economic performance for the accounting period and the negative equity gives a positive value, as well as a productivity indicator expressed by the ratio of value added to sales, because of a high degree of correlation. 
Table 1. Variables entering the analysis.

\begin{tabular}{cl}
\hline Variable & \multicolumn{1}{c}{ Description } \\
\hline$x_{1}$ & $\begin{array}{l}\text { Accounts payable turnover ratio (APTR), the time during which the company } \\
\text { pays its trade obligations }\end{array}$ \\
& $\begin{array}{l}\text { Return on sales (ROS) = earnings before interest, taxes, depreciation and } \\
\text { amortization (EBITDA)/sales, }\end{array}$ \\
$x_{2}$ & Return on investments (ROI) = earnings before interest, taxes (EBT)/total capital \\
$x_{3}$ & quick ratio (QR) $=($ current assets - inventory)/current liabilities \\
$x_{4}$ & sales/assets \\
$x_{5}$ & Foreign capital/assets \\
$x_{6}$ & Financial leverage (FL) = assets/equity \\
$x_{7}$ & Net working capital (NWC)/assets (A) \\
$x_{8}$ &
\end{tabular}

We interpreted the results according to [78]. Because explanatory variables should not be highly intercorrelated, we calculated the correlation matrix given in Table 2.

Table 2. Pearson's correlation between independent variables of the models $(n=856)$.

\begin{tabular}{ccccccccc}
\hline \multicolumn{7}{c}{ Variables } \\
\hline$x_{1}$ & $x_{2}$ & $x_{3}$ & $x_{4}$ & $x_{5}$ & $x_{6}$ & $x_{7}$ & $x_{8}$ & \\
1 & 0.0013 & -0.0559 & -0.0032 & -0.0317 & $0.5875^{\mathrm{d}}$ & -0.0037 & -0.0007 & $x_{1}$ \\
& 1 & 0.0034 & 0.0022 & 0.0346 & 0.0010 & 0.0048 & $0.3036^{\mathrm{d}}$ & $x_{2}$ \\
& 1 & 0.0025 & 0.0265 & $-0.8403 \mathrm{~d}$ & 0.0034 & 0.0017 & $x_{3}$ \\
& & 1 & -0.0414 & -0.0039 & -0.0067 & 0.0271 & $x_{4}$ \\
& & & & 1 & -0.036 & -0.0209 & -0.0238 & $x_{5}$ \\
& & & & 1 & -0.0047 & -0.0020 & $x_{6}$ \\
& & & & & & 1 & -0.0028 & $x_{7}$ \\
& & & & & & & 1 & $x_{8}$ \\
\hline
\end{tabular}

Note: ${ }^{\mathrm{d}}$ denotes statistical significance at the $0.1 \%$ level.

Given that logistic regression does not require initial selection of indicators, performing a one-dimensional analysis is not required. Collinearity has been validated (variance inflation factor, condition index) and it has not been proven. For the construction of logistic regression models, the stepwise method was used, testing the significance of adding or eliminating the variable at each step.

For a set of 856 non-financial corporations, a model was suggested with predictors $x_{1}, x_{2}, x_{4}, x_{7}$ and $x_{8}$ (Table 3 ). The Wald test showed a significant benefit of these predictors in the model. The logistic regression model can be written as

$$
\ln \frac{p}{1-p}=-1498+0.0218 \cdot A P T R-1987 \cdot R O S-10,192 \cdot Q R+0.074 \cdot F L-0.370 \cdot N W C / A
$$

Table 3. Analysis of maximum likelihood estimates.

\begin{tabular}{lcccccc}
\hline \multicolumn{1}{c}{ Variable } & B & S.E. & Wald Chi-Square & OR & LCI & UCI \\
\hline Intercept & $-1.4988^{\mathrm{d}}$ & 0.2687 & 31.1176 & & & \\
$\mathrm{x}_{1}-\mathrm{APTR}$ & $0.0218^{\mathrm{d}}$ & 0.0083 & 6.7724 & $\mathbf{1 . 0 2 2}$ & 1.005 & 1.039 \\
$\mathrm{x}_{2}-\mathrm{ROS}$ & $-1.9878^{\mathrm{d}}$ & 0.3673 & 29.2940 & $\mathbf{0 . 1 3 7}$ & 0.067 & 0.281 \\
$\mathrm{x}_{4}-\mathrm{QR}$ & $-1.0192^{\mathrm{d}}$ & 0.2617 & 15.1703 & 0.361 & 0.216 & 0.603 \\
$\mathrm{x}_{7}-\mathrm{FL}$ & $0.0740^{\mathrm{d}}$ & 0.0126 & 34.7365 & 1.086 & 1.051 & 1.104 \\
$\mathrm{x}_{8}-\mathrm{NWC} / \mathrm{A}$ & $-0.3705^{\mathrm{d}}$ & 0.0970 & 14.5914 & 0.592 & 0.571 & 0.835 \\
\hline
\end{tabular}

Note: B denotes coefficient, S.E. is standard deviation, OR denotes odds ratio, $\mathrm{LCI}$ is lower $95 \%$ Wald confidence interval for OR, UCI denotes upper \% Wald confidence interval for OR, and ${ }^{\mathrm{d}}$ denotes statistical significance at the $0.1 \%$ level. 
For the continuous variable $x$ with the slope, the $\exp (B)$ value can be interpreted as a relative positive likelihood ratio for an enterprise with an $x+1$ value to a positive likelihood ratio for an $x$-value enterprise. Odds Ratio is a positive number, if greater than 1 , then the likelihood of the event happening increases; if less than 1, then decreases. Odds ratio $\left(\mathrm{e}^{B}\right)$ means that if, for example, the independent variable $x_{1}$ (Accounts payable turnover ratio) is increased by one-unit, then the estimated bankruptcy odds at the other fixed predictors is increased by a multiple of $\mathrm{e}^{0.0218}=1.022$. Therefore, if $x_{1}$ increases by one-unit, the odds ratio is 1.022 times greater. We display odds ratios with $95 \%$ Wald confidence limits in Figure 2.

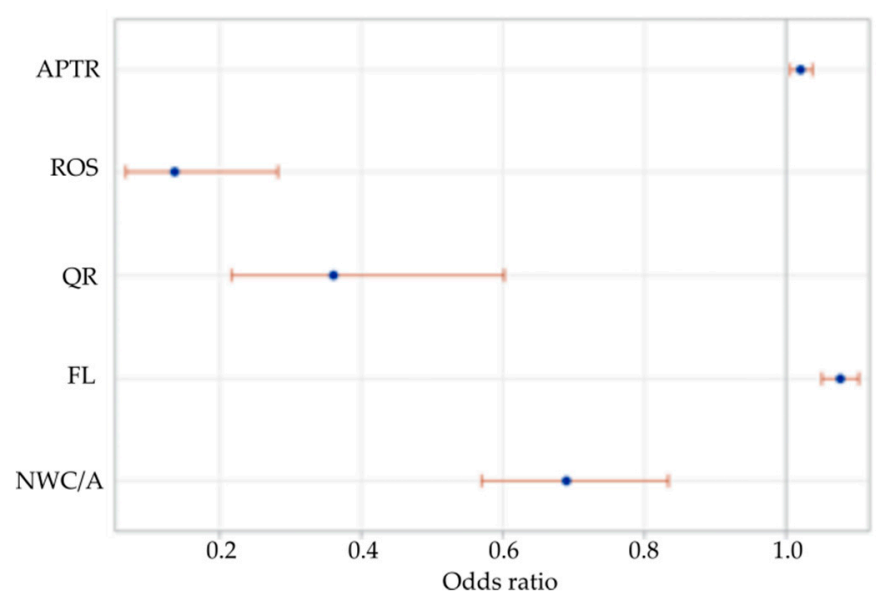

Figure 2. Odds ratios with $95 \%$ Wald confidence limits.

The Nagelkerke $R^{2}$ statistics (Adjusted Cox and Snell $R^{2}$ ) at 0.581 indicates $58.1 \%$ of variation in the response is explained by the model that predicts default (Table 4). The absolute value responds to the threshold. This value differs from the splitting threshold in discriminatory analysis. The clarification of this disagreement lies in the fact that the logistic regression program uses implicit estimates of the probability obtained from the selection. In Table 5, we present association of predicted probabilities and observed responses.

Table 4. Model fit statistics.

\begin{tabular}{cc}
\hline Criterion & Intercept and Covariates \\
\hline Akaike criterion & 351.069 \\
Schwarz criterion & 379.540 \\
Hannan-Quinn criterion & 381.310 \\
-2 Log L & 339.069 \\
Cox and Snell $\mathrm{R}^{2}$ & 0.313 \\
Nagelkerke $\mathrm{R}^{2}$ & 0.581 \\
McFadden & 0.455 \\
\hline
\end{tabular}

Table 5. Association of predicted probabilities and observed responses.

\begin{tabular}{cccc}
\hline Characteristics & Value & Characteristics & Value \\
\hline Percent Concordant & 95.4 & Somers' D & 0.907 \\
Percent Discordant & 4.6 & Gamma & 0.907 \\
Percent Tied & 0 & Tau-a & 0.206 \\
Pairs & 82,029 & c & 0.954 \\
\hline
\end{tabular}

Model discrimination can be judged by the area under the ROC curve, which indicates the likelihood that a bankrupt company has a higher predicted bankruptcy likelihood than a company that is not bankrupt. Curves must pass through points $(0,0)$ and $(1,1)$. The smallest cut-off point is the 
minimum observed test value minus 1 and the highest cut-off point is the maximum observed test value plus 1. All other cut-off values are the averages of two consecutive ordered observed test values. The ROC curve for the model (Table 6 and Figure 3) defines an area under a curve equal to 0.954. The likelihood that a company in a crisis has a higher predicted probability than a company that is not in crisis is; therefore, 0.954. The 0.9-1.0 interval for AUC and model quality is excellent. The area under the curve (AUC) is a popular criterion for evaluating the correctness of the proposed logistic model. Most programs choose a model based on the largest AUC.

Table 6. Quality of model-AUC.

\begin{tabular}{ccccc}
\hline \multirow{2}{*}{ Area } & S.E. & \multirow{2}{*}{ Sig.b } & \multicolumn{2}{c}{ Asymptotic 95\% Confidence Interval } \\
\cline { 3 - 5 } & & & Lower Bound & Upper Bound \\
\hline 0.9535 & 0.012 & 0.000 & 0.930 & 0.977 \\
\hline \multicolumn{2}{r}{ Note: S.E. denotes standard deviation, Sig.b denotes statistical significance. }
\end{tabular}

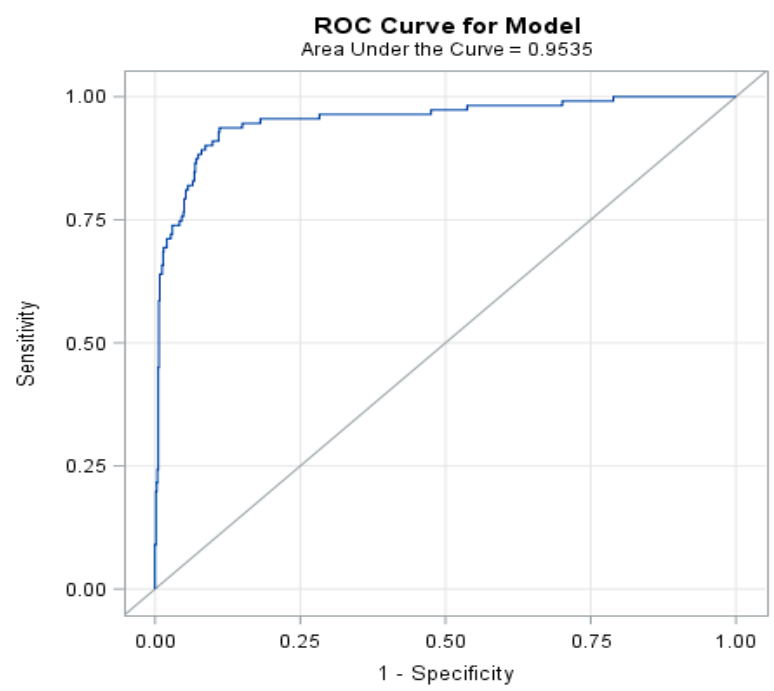

Figure 3. ROC curve.

In Table 7, we present classification table for the model. Extended version of this table is in the Appendix A (Table A1).

Table 7. Classification table for model.

\begin{tabular}{clccc}
\hline & & \multicolumn{2}{c}{ INTO } & Total \\
\hline FROM & & 0 & 1 & $\mathbf{7 3 9}$ \\
1 & Frequency & 733 & 6 & $\mathbf{1 1 1}$ \\
Total & Frequency & 45 & 66 & $\mathbf{8 5 0}$ \\
\hline
\end{tabular}

Frequency Missing $=6$

Note: FROM denotes formatted value of the observed response, INTO denotes formatted value of the predicted response.

\section{Discussion and Conclusions}

We modeled a binary variable (default) depending on five explanatory variables (predictors). The logistic model was statistically significant as a whole. In the bankruptcy model for the electrical engineering industry, the estimated odds ratios have shown that the odds of bankruptcy significantly reduces the financial indicators ROS, QR and NPW/A. As these indicators grow, the likelihood of a 
business failure is reduced. When return on sales is raised by one-unit and the other predictors stay fixed, the probability of bankruptcy decreases 7.29 times. Current profitability will cut bankruptcy by 2.77 times and the share of net working capital on assets will reduce the chance of bankruptcy 1.69 times. The financial indicators of APTR and FL are statistically significant. Although there is only a slight increase in the probability of bankruptcy for a one-unit change in these indicators, they still need to be monitored. The overall success rate for the electrical engineering industry was $94 \%$. Therefore, we confirm hypothesis H1.

Our results can be compared with several existing studies that deal with bankruptcy models in similar conditions. Therefore, we select only the results of analyzes for the Czech and Slovak Republics [61-69]. Each of these studies uses different financial indicators, but indicators of activity, profitability, liquidity, and indebtedness are always represented. Taking into account the statistically significant variables of our model, the same activity indicator (APTR) can be found in [69], profitability (ROS) in [64], liquidity (QR) in [64], and indebtedness (FL) in [62]. The remaining studies use completely different indicators, and our liquidity indicator (NWC/A) is not used in any of them.

A prerequisite for follow-up research is to verify the proposed model using further econometric verification tests, and to estimate model for longer time series. For further research and modeling using logistic regression, it is necessary to take into account other variables (e.g., qualitative variables, the variable relating to the region, and the variable relating to the size of the business entity), because the size of the business is an important factor in predicting the failure of the newly established firms. Small businesses are more susceptible to bankruptcy than large corporations. For larger companies, lower probability is assumed, as their size allows for more comprehensive transactions on more favorable terms, and so on.

The presented results are the basis for further modeling, and at the same time a source of stimulus for further discussion. In comparing models, we will focus on compiling different predictive models, using a variety of methods (e.g., using the neural network method). We expect the carry out of research that will follow the latest trends in the field (e.g., machine learning).

The main limitation of our paper is that we analyze only the year 2017. However, according to financial statements, the analyzed companies showed similar results in terms of EBIT after three consecutive years. It will be interesting to compare the model with the period 2020 when the corona crisis will significantly negatively affect the automotive industry, and this will have a negative impact on the electrical engineering industry. Despite unexpected events, the model created for companies that operate in the electrical engineering industry can be implemented in companies that operate in the mechanical engineering industry in the conditions of Slovakia.

The importance to assess the financial health of the company lies in a necessity to identify and prevent the birth of instability in the corporate body in a timely fashion. This is only possible with the help of appropriate bankruptcy or creditworthy models. At present, the focus is mainly on ex-post financial analysis. The prediction of future developments as part of the assessment of a company's financial situation requires an expansion of the spectrum of mathematical and statistical methods. Comprehensive business evaluation methods are somewhat transparent but suffer from a lack of precision. It is; therefore, necessary for financial analysts to use the multiple predictive evaluation methods at the same time to clarify the financial health of a company for objective business appraisal. It is necessary to use more methods, compare their results and then predict the possible development of a business. Every financial analyst can generate his/her own model for assessing the financial situation of a business entity. In view of the results of this financial and economic analysis, the financial manager should be oriented to a single aggregate indicator, which could better examine and forecast the situation in that firm.

Author Contributions: Conceptualization, resources, data curation, writing-original draft preparation, investigation, software, S.J.; writing-formal conceptualization, P.V.; supervision, R.Š.; English correction, P.V. and R.Š.; funding acquisition, R.Š. and S.J.; resources, S.J. and P.V. All authors have read and agreed to the published version of the manuscript. 
Funding: This research was funded by the Scientific Grant Agency of the Ministry of Education, Science, Research, and Sport of the Slovak Republic and the Slovak Academy of Sciences, grant numbers VEGA 1/0194/19 and VEGA $1 / 0741 / 20$.

Acknowledgments: The authors also thank the journal editor and anonymous reviewers for their guidance and constructive suggestions.

Conflicts of Interest: The authors declare no conflict of interest.

\section{Appendix A}

Table A1. Classification table for model (extended version).

\begin{tabular}{|c|c|c|c|c|c|c|c|c|c|}
\hline \multirow{2}{*}{ PL } & \multicolumn{2}{|c|}{ Correct } & \multicolumn{2}{|c|}{ Incorrect } & \multicolumn{5}{|c|}{ Percentages } \\
\hline & $\mathbf{E}$ & NE & E & $\mathrm{NE}$ & Correct & Sensitivity & Specificity & False POS & False NEG \\
\hline 0.000 & 111 & 0 & 739 & 0 & 13.1 & 100.0 & 0.0 & 86.9 & 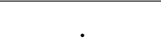 \\
\hline 0.020 & 108 & 338 & 401 & 3 & 52.5 & 97.3 & 45.7 & 78.8 & 0.9 \\
\hline 0.040 & 107 & 414 & 325 & 4 & 61.3 & 96.4 & 56.0 & 75.2 & 1.0 \\
\hline 0.060 & 107 & 473 & 266 & 4 & 68.2 & 96.4 & 64.0 & 71.3 & 0.8 \\
\hline 0.080 & 107 & 523 & 216 & 4 & 74.1 & 96.4 & 70.8 & 66.9 & 0.8 \\
\hline 0.100 & 106 & 573 & 166 & 5 & 79.9 & 95.5 & 77.5 & 61.0 & 0.9 \\
\hline 0.120 & 104 & 617 & 122 & 7 & 84.8 & 93.7 & 83.5 & 54.0 & 1.1 \\
\hline 0.140 & 101 & 655 & 84 & 10 & 88.9 & 91.0 & 88.6 & 45.4 & 1.5 \\
\hline 0.160 & 97 & 675 & 64 & 14 & 90.8 & 87.4 & 91.3 & 39.8 & 2.0 \\
\hline 0.180 & 90 & 690 & 49 & 21 & 91.8 & 81.1 & 93.4 & 35.3 & 3.0 \\
\hline 0.200 & 85 & 702 & 37 & 26 & 92.6 & 76.6 & 95.0 & 30.3 & 3.6 \\
\hline 0.220 & 82 & 708 & 31 & 29 & 92.9 & 73.9 & 95.8 & 27.4 & 3.9 \\
\hline 0.240 & 80 & 717 & 22 & 31 & 93.8 & 72.1 & 97.0 & 21.6 & 4.1 \\
\hline 0.260 & 78 & 719 & 20 & 33 & 93.8 & 70.3 & 97.3 & 20.4 & 4.4 \\
\hline 0.280 & 78 & 722 & 17 & 33 & 94.1 & 70.3 & 97.7 & 17.9 & 4.4 \\
\hline 0.300 & 77 & 725 & 14 & 34 & 94.4 & 69.4 & 98.1 & 15.4 & 4.5 \\
\hline 0.320 & 75 & 728 & 11 & 36 & 94.5 & 67.6 & 98.5 & 12.8 & 4.7 \\
\hline 0.340 & 73 & 729 & 10 & 38 & 94.4 & 65.8 & 98.6 & 12.0 & 5.0 \\
\hline 0.360 & 71 & 729 & 10 & 40 & 94.1 & 64.0 & 98.6 & 12.3 & 5.2 \\
\hline 0.380 & 71 & 732 & 7 & 40 & 94.5 & 64.0 & 99.1 & 9.0 & 5.2 \\
\hline 0.400 & 70 & 733 & 6 & 41 & 94.5 & 63.1 & 99.2 & 7.9 & 5.3 \\
\hline 0.420 & 70 & 733 & 6 & 41 & 94.5 & 63.1 & 99.2 & 7.9 & 5.3 \\
\hline 0.440 & 70 & 733 & 6 & 41 & 94.5 & 63.1 & 99.2 & 7.9 & 5.3 \\
\hline 0.460 & 69 & 733 & 6 & 42 & 94.4 & 62.2 & 99.2 & 8.0 & 5.4 \\
\hline 0.480 & 67 & 733 & 6 & 44 & 94.1 & 60.4 & 99.2 & 8.2 & 5.7 \\
\hline 0.500 & 64 & 733 & 6 & 47 & 93.8 & 57.7 & 99.2 & 8.6 & 6.0 \\
\hline 0.520 & 62 & 734 & 5 & 49 & 93.6 & 55.9 & 99.3 & 7.5 & 6.3 \\
\hline 0.540 & 59 & 734 & 5 & 52 & 93.3 & 53.2 & 99.3 & 7.8 & 6.6 \\
\hline 0.560 & 57 & 734 & 5 & 54 & 93.1 & 51.4 & 99.3 & 8.1 & 6.9 \\
\hline 0.580 & 56 & 734 & 5 & 55 & 92.9 & 50.5 & 99.3 & 8.2 & 7.0 \\
\hline 0.600 & 55 & 734 & 5 & 56 & 92.8 & 49.5 & 99.3 & 8.3 & 7.1 \\
\hline 0.620 & 54 & 734 & 5 & 57 & 92.7 & 48.6 & 99.3 & 8.5 & 7.2 \\
\hline 0.640 & 54 & 734 & 5 & 57 & 92.7 & 48.6 & 99.3 & 8.5 & 7.2 \\
\hline 0.660 & 53 & 734 & 5 & 58 & 92.6 & 47.7 & 99.3 & 8.6 & 7.3 \\
\hline 0.680 & 52 & 734 & 5 & 59 & 92.5 & 46.8 & 99.3 & 8.8 & 7.4 \\
\hline 0.700 & 51 & 734 & 5 & 60 & 92.4 & 45.9 & 99.3 & 8.9 & 7.6 \\
\hline 0.720 & 49 & 734 & 5 & 62 & 92.1 & 44.1 & 99.3 & 9.3 & 7.8 \\
\hline 0.740 & 48 & 734 & 5 & 63 & 92.0 & 43.2 & 99.3 & 9.4 & 7.9 \\
\hline 0.760 & 46 & 734 & 5 & 65 & 91.8 & 41.4 & 99.3 & 9.8 & 8.1 \\
\hline 0.780 & 43 & 734 & 5 & 68 & 91.4 & 38.7 & 99.3 & 10.4 & 8.5 \\
\hline 0.800 & 39 & 734 & 5 & 72 & 90.9 & 35.1 & 99.3 & 11.4 & 8.9 \\
\hline 0.820 & 39 & 734 & 5 & 72 & 90.9 & 35.1 & 99.3 & 11.4 & 8.9 \\
\hline 0.840 & 36 & 734 & 5 & 75 & 90.6 & 32.4 & 99.3 & 12.2 & 9.3 \\
\hline 0.860 & 33 & 734 & 5 & 78 & 90.2 & 29.7 & 99.3 & 13.2 & 9.6 \\
\hline 0.880 & 32 & 734 & 5 & 79 & 90.1 & 28.8 & 99.3 & 13.5 & 9.7 \\
\hline
\end{tabular}


Table A1. Cont.

\begin{tabular}{|c|c|c|c|c|c|c|c|c|c|}
\hline \multirow{2}{*}{ PL } & \multicolumn{2}{|c|}{ Correct } & \multicolumn{2}{|c|}{ Incorrect } & \multicolumn{5}{|c|}{ Percentages } \\
\hline & E & NE & $\mathbf{E}$ & NE & Correct & Sensitivity & Specificity & False POS & False NEG \\
\hline 0.900 & 31 & 734 & 5 & 80 & 90.0 & 27.9 & 99.3 & 13.9 & 9.8 \\
\hline 0.920 & 30 & 734 & 5 & 81 & 89.9 & 27.0 & 99.3 & 14.3 & 9.9 \\
\hline 0.940 & 30 & 735 & 4 & 81 & 90.0 & 27.0 & 99.5 & 11.8 & 9.9 \\
\hline 0.960 & 26 & 735 & 4 & 85 & 89.5 & 23.4 & 99.5 & 13.3 & 10.4 \\
\hline 0.980 & 22 & 736 & 3 & 89 & 89.2 & 19.8 & 99.6 & 12.0 & 10.8 \\
\hline 1.000 & 0 & 739 & 0 & 111 & 86.9 & 0.0 & 100.0 & . & 13.1 \\
\hline
\end{tabular}

Note: PL denotes probability level, $\mathrm{E}$ is event, NE is non-event, POS denotes positive, NEG denotes negative. The table displays probability that a firm in bankruptcy was ranked among firms in bankruptcy, and the probability that prosperous firm was ranked among prosperous firms.

\section{References}

1. Statistical Office of the Slovak Republic. DATAcube. Available online: http://datacube.statistics.sk/ (accessed on 31 July 2020).

2. Mládek, J. Teritoriálne Priemyselné Útvary Slovenska; Univerzita Komenského: Bratislava, Slovakia, 1990.

3. Dubcová, A.; Midler, M. Impact of foreign capital on disparities of electrical engineering industry in districts of Slovakia. Geogr. Inf. 2014, 18, 49-58. [CrossRef]

4. Kulla, M. Súčasný stav a vývojové trendy v elektrotechnickom priemysle Slovenska. Acta Geogr. Univ. Comen. 2013, 57, 31-49.

5. Mišunová, E.; Mišun, J. Priemysel Slovenska a Dopady Globálnej Krízy. Globálna Kríza s Akcentom na Automobilový Priemysel; Espirit: Bratislava, Slovak, 2009.

6. Laatu, M.; Takala, J. Implementing European quality award in a global high tech company. Int. J. Technol. Manag. 1999, 17, 869-884. [CrossRef]

7. Fertala, N. Growth and competition in the economic "wonder years": The electrotechnical industry in the Federal Republic of Germany and in Great Britain, 1945-1967. Bus. Hist. 2005, 47, 311-312.

8. Plumpe, W. Growth and competition in the years of the Economic Miracle. The electrotechnical industry in the Federal Republic of Germany and in Great Britain, 1945-1967. Hist. Z. 2003, 277, 264-267.

9. Fischer, M.; Menschik, G. Innovations and technological-change in Austria. Mitt. Osterreichischen Geogr. Ges. 1991, 133, 43-68.

10. Jenčová, S. Aplikácia Pokročilých Metód vo Finančno-Ekonomickej Analýze Elektrotechnického Odvetvia Slovenskej Republiky; SAEI VŠB-TU Ostrava: Ostrava, Czech Republic, 2018.

11. Štefko, R.; Jenčová, S.; Vašaničová, P.; Litavcová, E. An Evaluation of Financial Health in the Electrical Engineering Industry. J. Compet. 2019, 11, 144-160.

12. Jenčová, S.; Vašaničová, P.; Litavcová, E. Financial indicators of the company from electrical engineering industry: The case study of Tesla, Inc. Serb. J. Manag. 2019, 14, 361-371. [CrossRef]

13. Jenčová, S.; Litavcová, E.; Vašaničová, P. Implementation of Du Pont model in non-financial corporations. Montenegrin J. Econ. 2018, 14, 131-141. [CrossRef]

14. Jenčová, S.; Litavcová, E.; Vašaničová, P. Implementation of financial and statistical models to study the electrical industry of the Slovak republic. In Political Sciences, Law, Finance, Economics and Tourism. In Proceedings of the 3rd International Multidisciplinary Scientific Conference Social Sciences \& Arts SGEM 2016, Sofia, Bulgaria, 22-31 August 2016; Sofia: STEF92 Technology: Sofia, Bulgaria, 2016; pp. 329-336.

15. Kislingerová, E.; Hnilica, J. Finanční Analýza-Krok za Krokem; C.H. Beck: Prague, Czech Republic, 2005.

16. Tamari, M. Financial ratios as a means of forecasting bankruptcy. Manag. Int. Rev. 1966, 4, 15-21.

17. Doucha, R. Finanční Analýza Podniku; Vox Consult: Praha, Czech Republic, 1996.

18. Fitzpatrick, P.J. A Comparison of ratios of successful industrial enterprises with those of failed firms. Certif. Public Account. 1932, 10, 598-605.

19. Smith, R.F.; Winakor, A.H. Changes in the Financial Structure of Unsuccessful Industrial Corporations; University of Illinois: Urbana, IL, USA, 1935.

20. Merwin, C.L. Financing Small Corporations in Five Manufacturing Industries, 1926-1936; National Bureau of Economic Research: New York, NY, USA, 1942. 
21. Chudson, W.A. A Survey of Corporate Financial Structure; National Bureau of Economic Research: New York, NY, USA, 1945.

22. Walter, J. Determination of technical insolvency. J. Bus. 1957, 30-43. [CrossRef]

23. Jackendoff, N. A study of published industry financial and operating ratios. Bur. Econ. Bus. Res. 1962, 52.

24. Beaver, W. Financial ratios predictors of failure. Empirical research in accounting selected studies. J. Account. Res. 1966, 4, 71-111. [CrossRef]

25. Delina, R.; Packová, M. Validácia predikčných bankrotových modelov v podmienkach SR. E + M. Ekonómie Manag. 2013, 16, 101-112.

26. Altman, E.I. Financial ratios, discriminant analysis and the prediction of corporate bankruptcy. J. Financ. 1968, 23, 589-609. [CrossRef]

27. Altman, E.I. Predicting financial distress of companies: Revisiting the Z-Score and ZETA@models. In Handbook of Research Methods and Applications in Empirical Finance Chapters; Bell, A.R., Brooks, C., Prokopczuk, M., Eds.; Edward Elgar Publishing: Cheltenham Glos, UK, 2013; Volume 1, pp. 428-456.

28. Altman, E.I.; Iwanicz-Drozdowska, M.; Laitinen, E.K.; Suvas, A. Distressed firm and bankruptcy prediction in an international context: A review and empirical analysis of Altman's Z-Score Model. SSRN Electron. J. 2014, 47. [CrossRef]

29. Deakin, E. A discriminant analysis of predictors of business failure. J. Account. Res. 1972, 10, 167-179. [CrossRef]

30. Blum, M. Failing company discriminant analysis. J. Account. Res. 1974, 12, 1-25. [CrossRef]

31. Sinkey, J.F. A multivariate statistical analysis $F$ the characteristics of problem banks. J. Financ. 1975, 20, 21-36. [CrossRef]

32. Beerman, K. Possible Ways of Predict Capital Losses with Annual Financial Statements; University of Düsseldorf: Dusseldorf, Germany, 1976.

33. Taffler, R.J.; Tisshaw, H. Going Gone-Four Factors which predict. Accountancy 1977, 88, 50-54.

34. Taffler, R.J.; Tseung, M. Going, going, going-Four factors which predict. Account. Mag. 1984, 88, $263-269$.

35. Springate, G.L. Predicting the Possibility of Failure in a Canadian Firm. Ph.D. Thesis, Simon Fraser University, Burnaby, Canada, 1978. Unpublished Work.

36. Sands, E.G.; Springate, G.L.; Var, T. Predicting business failures. CGA Mag. 1983, 24-27.

37. Fulmer, J.G.J.; Moon, J.E.; Gavin, T.A.; Erwin, M.J. Bankruptcy classification model for small firms. J. Commer. Bank Lend. 1984, 25-37.

38. Marais, D.A.J. A Method of Quantifying Companies Relative Financial Strength; Bank of England: London, UK, 1979.

39. Bilderbeek, J. An empirical study of the predictive ability of financial ratios in The Netherlands. Zeitschift Betr. 1979, 5, 388-407.

40. Lussier, R.N. A nonfinancial business success versus failure prediction model for young firms. J. Small Bus. Manag. 1995, 33, 8-20.

41. Laitinen, E.K. Traditional versus operating cash flow in failure prediction. J. Bus. Financ. Account. 1994, 21, 215-228. [CrossRef]

42. Neumaierová, I.; Neumaier, I. Proč se ujal index IN a nikoli pyramídový systém ukazatelů INFA. Ekon. Manag. 2008, 2, 12-19.

43. Virag, M.; Nyitrai, T. Is There a Trade-off between the predictive power and the interpretability of bankruptcy models? The case of the first Hungarian bankruptcy prediction model. Acta Oeconomica 2014, 64, 19-440. [CrossRef]

44. Gurčík, L'. G-index-metóda predikcie finančného stavu pol'nohospodárskych podnikov. Zemědělská Ekon. 2002, 48, 373-378.

45. Chrastinová, Z. Metódy Hodnotenia Ekonomickej Bonity a Predikcie Finančnej Situácie Pol'nohospodárskych Podnikov; VÚEPP: Bratislava, Slovak, 1998.

46. Kameníková, K. Obmedzenia použitia modelov predikcie finančného vývoja podniku v podmienkach Slovenskej republiky. Acta Montan. Slovaca 2005, 10, 337-343.

47. Pilch, C. K modelom hodnotenia finančného zdravia podniku. 3. čast'. Finančné Trhy 2008, 5, 1-9.

48. Pilch, C. K modelom hodnotenia finančného zdravia podniku. 4. čast'. Finančné Trhy 2008, 5, 1-7. 
49. Bondareva, I. Analysis of explanatory models of the predictive ability of the financial condition of the company in Slovakia. In Proceedings of the Manažment Podnikania a Vecí Verejných: Zborník Vedeckých Prác; SAM: Bratislava, Slovakia, 2011; pp. 59-64.

50. Kadarová, J.; Turisová, R. Finančné modely predikcie finančných problémov v priemyselných podnikoch. In Modelování, Simulace a Optimalizace Podnikových Procesů v Prax, Proceedings of the Sborník z Konference, Prague, Czech Republic, 29 March 2011; Tuček, D., Ed.; ČSOP: Prague, Czech Republic, 2011; pp. 167-173.

51. Malega, P.; Bjalončíkováa, M. Analýza Finančného Zdravia Spoločnosti. In Zbornik Vedeckých Prác Katedry Ekonómie a Ekonomiky ANNO; Kotulič, R., Ed.; University of Prešov: Prešov, Slovakia, 2012; pp. 171-183.

52. Kabát, L.; Sobeková Majková, M.; Vincúrová, Z. Hodnotenie Podniku a Analýza Jeho Finančného Zdravia; Iura Edition: Bratislava, Slovak, 2013.

53. Gundová, P. Využitie metód multikriteriálneho hodnotenia a neurónových sietí vo finančnom riadení a rozhodovaní. In Proceedings of the MERKUR 2012, Ekonóm: Brartislava, Bratislava, Slovakia, 6-7 December 2012; pp. 1-16.

54. Gundová, P. Verifikácia vybraných predikčných metód na vzorke Slovenských podnikov. Acta Acad. Karviniensia 2014, 17, 26-38. [CrossRef]

55. Ohlson, J.A. Financial Ratios and the Probabilistic Prediction of Bankruptcy. J. Account. Res. 1980, 18, $109-131$. [CrossRef]

56. Zavgren, C.V. Assessing the vulnerability to failure of American industrial firms: A logistic analysis. J. Bus. Financ. Account. 1985, 12, 19-45. [CrossRef]

57. Jabeur, S.B. Bankruptcy prediction using partial least squares logistic regression. J. Retail. Consum. Serv. 2017, 36, 197-202. [CrossRef]

58. Wang, Y. Financial ratios and the prediction of bankruptcy: The Ohlson model applied to Chinese publicly traded companies. J. Organ. Leadersh. Bus. 2010, 5, 1-15.

59. Marcinkevičius, R.; Kanapickienè, R. Bankruptcy prediction in the sector of construction in Lithuania. Procedia Soc. Behav. Sci. 2014, 156, 553-557. [CrossRef]

60. Slavíček, O.; Kuběnka, M. Bankruptcy prediction models based on the logistic regression for companies in the Czech Republic. In Proceedings of the 8th International Scientific Conference Managing and Modelling of Financial Risks, Ostrava, Czech Republic, 5-6 September 2016; pp. 924-931.

61. Režňáková, M.; Karas, M. Bankruptcy Prediction Models: Can the prediction power of the models be improved by using dynamic indicators? Procedia Econ. Financ. 2014, 12, 565-574. [CrossRef]

62. Jakubík, P.; Teplý, P. The JT Index as indicator of financial stability of corporate sector. Prague Econ. Pap. 2011, 20, 157-176. [CrossRef]

63. Gurný, P.; Gurný, M. Logit and probit model within estimation of US banks. In Proceedings of the 47th EWGFM Meeting, Ostrava, Czech Republic, 28-30 October 2010; pp. 73-80.

64. Valecký, J.; Slivková, E. Mikroekonomický scoringový model úpadku českých podniků. Ekon. Rev. ER-CEREI 2012, 15, 15-26. [CrossRef]

65. Binkert, C.H.H. Fruherkennung von Unternehmenskrisen mit Hilfe Geeigneter Methoden im Deutschen und Slowakischen Wirtschaftsraum. Ph.D. Thesis, University of Economics in Bratislava, Bratislava, Slovakia, 1999.

66. Hurtosova, J. Konštrukcia Ratingového Modelu, Nástroja Hodnotenia Úverovej Spôsobilosti Podniku. Ph.D. Thesis, Economic University in Bratislava, Bratislava, Slovakia, 2009.

67. Vlkolinský, P. Prehl'ad vývoja ratingových modelov vo vybranných krajinách. Finančný Manažér 2013, 13, $17-27$.

68. Kováčova, M.; Klieštik, T. Logit and Probit application for the prediction of bankruptcy in Slovak companies. Equilibrium. Q. J. Econ. Econ. Policy 2017, 12, 775-791.

69. Harumová, A.; Janisová, M. Hodnotenie slovenských podnikov pomocou skóringovej funkcie. Ekon. Časopis 2014, 62, 522-539.

70. Sharda, R.; Wilson, R.L. Neural network experiments in business-failure forecasting: Predictive performance measurement issues. Int. J. Comput. Intell. Organ. 1996, 1, 107-117.

71. Alaka, H.A.; Oyedele, L.O.; Owolabi, H.A.; Kumar, V.; Ajayi, S.O.; Akinade, O.O.; Bilal, M. Systematic review of bankruptcy prediction models: Towards a framework for tool selection. Expert Syst. Appl. 2018, 94, 164-184. [CrossRef] 
72. Taffler, R.J. Forecasting companyfailure in the UK using discriminant analysis and financial ratio data. J. R. Stat. Soc. 1982, 145, 342-358.

73. Tsindeliani, I.; Kot, S.; Vasilyeva, E.; Narinyan, L. Tax system of the russian federation: Current state and steps towards financial sustainability. Sustainability 2019, 11, 6994. [CrossRef]

74. Hussain, H.I.; Kot, S.; Thaker, H.M.T.; Turner, J.J. Environmental reporting and speed of adjustment to target leverage: Evidence from a dynamic regime switching model. Organizacija 2020, 53, 21-35. [CrossRef]

75. Zmijewski, M.E. Methodological issues related to the estimation of financial distress prediction models. J. Account. Res. 1984, 22, 59-86. [CrossRef]

76. Zalai, K.; Dávid, A.; Šnircová, J.; Moravčíková, E.; Hurtošová, J.; Tučníková, D. Finančno-Ekonomická Analýza; Sprint Dva: Bratislava, Slovakia, 2016.

77. Stankovičová, I.; Vojtková, M. Viacrozmerné Štatistické Metódy s Aplikáciami; Grada Publishing: Praha, Czech Republic, 2007.

78. Hosmer, D.W.; Lemeshow, S. Applied Logistic Regresion; Wiley: New York, NY, USA, 1989.

79. Hosmer, D.W.S.; Lemeshow, S.; Sturdivant, R.X. Applied Logistic Regression, 3rd ed.; Wiley: New York, NY, USA, 2013.

80. Act No. 513/1991 Coll. Commercial Code; Iura Edition: Bratislava, Slovakia, 2013.

81. Act No. 7/2005 Coll. Bankruptcy and Restructuring; Iura Edition: Bratislava, Slovakia, 2013.

(C) 2020 by the authors. Licensee MDPI, Basel, Switzerland. This article is an open access article distributed under the terms and conditions of the Creative Commons Attribution (CC BY) license (http://creativecommons.org/licenses/by/4.0/). 